\title{
Within the Scope of Right to Fair Trial the Principle of "Forum Necessitatis" and Its Effect on Turkish International Jurisdiction Rules
}

\author{
Adil Yargılanma Hakkı Kapsamında "Forum Necessitatis" İlkesi ve Türk \\ Milletlerarası Yetki Kurallarına Etkisi
}

\section{Gizem Ersen Perçin * (iD)}

\begin{abstract}
As a human right, the right of access to court is within the scope of the right to a fair trial and limited by the decisions of the European Court of Human Rights. In private law disputes involving foreign element, the negative conflict of international jurisdiction rules of the state's results in the plaintiff's inability to find a court to open her/his case. Also in the cases lack of jurisdiction agreement, the plaintiff whose right of access to the court is violated, can only access a court with the initiation of the principle of forum necessitatis. In order to have a court involving international jurisdiction by the application of the principle of forum necessitatis, it must be impossible to file the case in another state and there must be a reasonable link between the state applying the principle of the forum necessitatis and the dispute. The broad interpretation of the exceptional principle of forum necessitatis will cause the states to apply exorbitant jurisdiction rules. This situation may prejudice the defendant's right to defence as well as preventing the recognition and enforcement of the decisions given by the courts having exorbitant jurisdiction. It is crucial to determine the boundaries of the principle of forum necessitatis in order to avoid experiencing mentioned negativities. In this study, the decisions of the European Court of Human Rights applying the forum necessitatis principle will be examined. Also the provisions of the European Union regulations and the law of some countries which regulate the principle of forum necessitatis will be mentioned. Finally, by explaining the judicial decisions on the subject in Turkish Law, it will be tried to determine whether there is a reflection of this principle on Turkish international jurisdiction rules.
\end{abstract}

Keywords: Right of Access to Court, Forum Necessitatis, Right to Fair Trial, European Court of Human Rights, International Jurisdiction

\section{öz}

Mahkemeye erişim hakkı, adil yargılanma hakkı kapsamında yer alan ve sınırları Avrupa İnsan Hakları Mahkemesi kararları ile belirlenen bir insan hakkıdır. Yabancılık unsuru içeren uyuşmazlıklarda devletlerin milletlerarası yetki kurallarının olumsuz çatışması, davacının davasını açacak bir mahkemeyi bulamaması sonucunu doğurur. Tarafların anlaşarak yetki sözleşmesi de yapmadığı bir durumda, mahkemeye erişim hakkı ihlal edilen davacı ancak forum necessitatis ilkesinin devreye girmesi ile milletlerarası yetkili bir mahkemeye ulaşabilir. Forum necessitatis ilkesinin uygulanması ile bir devlet mahkemesinin yetkilendirilebilmesi için bir başka devlette uyuşmazlık konusu davanın açılmasının imkansız olması ve forum necessitatis ilkesine başvuracak devlet ile uyuşmazlık arasında makul bir bağlantının bulunması gerekmektedir. İstisnai nitelik taşıyan forum necessitatis ilkesinin geniş yorumlanması devletlerin aşkın yetki kurallarına başvurmasına sebep olacaktır. Bu durum ise, davalının savunma hakkına zarar

* Asst. Prof. Dr. Istanbul Aydin University Law Faculty Private International Law Department. This study is created by the authors oral presentation named “Adil Yargılanma Hakkı Kapsamında Forum Necessitatis İlkesi ve Türk Milletlerarası Yetki Kurallarına Etkisi”, which took place in "Milletlerarası Usul Hukukunda Mahkemelerin Yetkisine İlişkin Güncel Tartışmalar" Symposium in Marmara University Law Faculty on 20.02. 2021.

Sorumlu Yazar/Correspondence Author: Gizem Ersen Perçin

E-posta/E-mail: gizempercin.@aydin.edu.tr

Geliş Tarihi/Received: $\quad 01.04 .2021$

Kabul Tarihi/Accepted:

25.05.2021 
verebileceği gibi bu tür mahkemelerden verilen kararların tanınması ve tenfizine de engel olacaktır. Söz konusu olumsuzlukların yaşanmaması bakımından forum necessitatis ilkesinin sınırlarının dikkatlice çizilmesi büyükönem arzetmektedir. Bu çalışmada Avrupa İnsan Hakları Mahkemesi’nin forum necessitatis ilkesini incelediği kararları irdelenecek, Avrupa Birliği düzenlemeleri ve bazı ülke hukuklarındaki konuya ilişkin hükümlere değinilecektir. Son olarak Türk Hukuku’nda konuya ilişkin yargı kararları açılanarak, milletlerarası yetki kurallarında bu ilkenin yansıması olup olmadığı tespit edilmeye çalışılacaktır.

Anahtar Kelimeler: Mahkemeye Erişim Hakkı, Forum Necessitatis, Adil Yargılanma Hakkı Avrupa İnsan Hakları Mahkemesi, Milletlerarası Yetki

\section{INTRODUCTION}

In private law disputes involving foreign element, each state determines whether it has international jurisdiction by applying its national procedural law regulations. This situation causes conflicts of jurisdiction between states. The situation where more than one states perceive themselves to be authorized for the same dispute due to this conflict of jurisdiction is called positive conflict of jurisdiction. A positive conflict of jurisdiction allows the plaintiff to file her/ his case by choosing one of the state courts which have international jurisdiction. The situation where none of the states have international jurisdiction under their national regulations, is called negative conflict of jurisdiction. A negative conflict of jurisdiction causes the result that the plaintiff cannot sue his /her dispute before the court of any state. Unless the parties agree on a jurisdiction agreement, this situation will cause the violation of the plaintiff's "right of access to court".

In order to prevent the violation of the right of access to court, the principle of "forum necessitatis" is put forward by the international doctrine. The application area of this principle should be kept limited; otherwise it causes exorbitant jurisdiction and indirectly the refusal of recognition and enforcement of the judicial decisions. So, it is crucial to determine the boundaries of the principle of "forum necessitatis".

In this study, first of all, the limits of the right of access to court will be tried to be drawn. Later on, the decisions of the European Court of Human Rights in which the principle of forum necessitatis is interpreted will be mentioned in order to prevent the violation of this right. As giving examples of European Union regulations involving the principle of forum necessitatis, the regulations in the domestic laws of some countries will be also mentioned. Finally, by explaining the judicial decisions on the subject in Turkish Law, it will be tried to determine whether there is a reflection of this principle on Turkish international jurisdiction rules. 


\section{THE RIGHT OF ACCESS TO COURT AS A PART OF THE RIGHT TO A FAIR TRIAL IN SCOPE OF THE EUROPEAN COURT OF HUMAN RIGHTS AND TURKISH CONSTITUTION}

Right to a fair trial is regulated in Article 6 of European Convention on Human Rights ${ }^{1}$. Although right of access to court is not regulated in the same article, it is declared as a part of right to fair trial on many decisions of the European Court of Human Rights. The right of access to court can be defined as having the necessary opportunities to file a lawsuit before a judicial body.

In decision of Golder v. United Kingdom (Application No. 4451/70), which was given by the European Court of Human Rights on 21 February 1975, was for the first time stated that the right of access to court is precondition of the right to a fair trial ${ }^{2}$. The decision of Home Secretary preventing Golder from contacting a solicitor, is accepted as a breach of the right of access to court which couses a violation of the right to a fair trial ${ }^{3}$. The aforementioned decision is crucial in terms of considering the right of access to court as a precondition of the right to a fair trial.

The paragraph 1 of Article 36 of 1982 Constitution of Turkey, titled "A. Freedom to claim rights", did not directly mention the right of access to the court by making a statement - «Everyone has the right of litigation either as plaintiff or defendant and the right to a fair trial before the courts through legitimate means and procedures.» However, in the decisions of the Constitutional Court, assessments were made regarding the right of access to the court.

In Sener Berçin decision of the Constitutional Court numbered 2013/5516 and dated 22.01.2015 the right of access to court, which is accepted as one of the fundamental elements of the right to a fair trial, is explained being able to bring a dispute to court and ask for the dispute to be resolved effectively (parg 52). In the relevant decision, it is emphasized that the European Court of Human Rights accepts the right of access to court as one of the basic elements of the "rule of law principle." In order to use the right of access to court effectively; there must be a consistent system of applying to the court and those who wish to file a lawsuit must have clear, practical and effective opportunities for access to the court. Therefore, in situations where legal or factual uncertainties damage the access of the parties to the court, decisions may be concluded that this right has been violated ${ }^{5}$.

1 It is an international convention to protect human rights, which is drafted by Council of Europe in 1950 and entered into force on in 1953. Turkey is a party of European Convention of Human Rights since 18 May 1954. For English version of this Convention, see, https://www.echr.coe.int/documents/convention_eng.pdf (31.03.2021)

2 For English version of full text, see, http://hudoc.echr.coe.int/eng?i=001-57496 (31.03.2021)

3 For more information about this decision, see, Gökhan Çayan, Avrupa İnsan Hakları Mahkemesi ve Anayasa Mahkemesi Kararları Işığında Mahkemeye Erişim Hakkı, Türkiye Adalet Akademisi Dergisi, (28), 2016, p. $237,239$.

4 Full text of this decision; see; https://cdn.istanbul.edu.tr/statics/idarehukuku-hukuk.istanbul.edu.tr/wp-content/ uploads/2017/01/Anayasa-Mahkemesi-\%C5\%9Eener-Ber\%C3\%A7in-Karar\%C4\%B1.pdf (31.03.2021)

5 Geffre v. France, Application No: 51307/99, 23/1/2003, parg. 34. 


\section{THE Characteristics of THE RIGHT OF ACCESS TO THE COURT}

Before mentioning the characteristics of the right of access to court, the term of "court" should be defined for determining the scope of this right. In the doctrine ${ }^{6}$, the court is qualified as «The authority that resolves the dispute that comes before it by making a proper settlement on matters falling under its jurisdiction» in accordance with Article 6 of the European Court of Human Rights. In that case, the following criteria should be sought by the decision-making authority in order to be qualified as a court;

1-) The parties should have procedural guarantees

2-) The court should be independent and impartial

3-) The court's decision should be based on the rule of law

4-) The decisions can be enforceable by public authority ${ }^{78}$

Therefore, although the authority that made the decisions meeting these criteria is not a state court, it should be accepted that the right of access to court is not prejudiced. For this reason, if the decisions made as a result of arbitration or mediation, meet the criteria mentioned above, it cannot be claimed that the right of access to court is violated.

In many decisions ${ }^{9}$ of the European Court of Human Rights, the right of access to court has been defined as a "concrete and effective" right. For the right of access to court to be concrete and effective, the plaintiff should have a clear and concrete opportunity to object for a transaction that constitutes an interference with her/his right ${ }^{10}$. The concrete and effective use of this right will serve the legal principle of clarity and definiteness ${ }^{11}$.

The situations such as excessive court costs, short term of litigation, excessively stringent burden of proof requirements are described as practices undermining the concrete and effective character of the right of access court in the European Court of Human Rights decisions ${ }^{12}$.

6 Hakan Pekcanitez, Medeni Yargıda Adil Yargılama, İzmir Barosu Dergisi, April 1997, p. 39.

7 Ayşe İpek Sarı̈z Büyükalp, Adil Yargılanma Hakkının Türk Milletlerarası Usul Hukuku Üzerindeki Etkileri, On İki Levha, 2018, p. 111.

8 Also, the foreign court decisions lacking of these criteria, cause the refusal of recognition and enforcement. See, Faruk Kerem Giray, Tenfize İlişkin Üç Soru: Tenfize Konu Yabanıı İlâmın Hukuk Devletinden Sadır Olması Gerekir Mi? Arabuluculuk Neticesinde Yapılan Sulh Anlaşması Tenfiz Edilebilir Mi? Yabancı Mahkemeden Sadır Ödeme Emri Kararı Tenfiz Edilebilir Mi?, MHB, (32), 2, 2019, p. 626-627 and 640.

9 For example, Bellet v. France parg. 38 ( 04.12.1995 dated and Application No: 23805/94) and Zubac v. Croatia parg. 76-79 ( 05.04.2018 dated and Application No:40160/12).

10 Bellet v. France parg. 36.

11 Işıl Özkan Adil Yargılanma Hakkının Uluslararası Özel Hukuka Etkisi, Dokuz Eylül Üniversitesi Hukuk Fakültesi Dergisi, Prof. Dr. Şeref Ertaş’a Armağan, (19), Special Edition, 2017,p.1777.

12 Guide on Article 6 of the European Convention on Human Rights - Right to Fair Trial parg 97. - (Updated: 31 August 2019). 


\section{THE BOUNDARIES OF RIGHT OF ACCESS TO THE COURT}

The first decision of European Court of Human Rights determining the criteria that states should comply with in limiting the right of access to court, is Ashingdane v. United Kingdom (dated 28.05.1985 and Application No: 8225/78). According to that decision, the limits of judicial discretion of the states are as followed; 13

1-) Limitations should not restrict the right to a degree that would prejudice its cause.

2-) Limitations must pursue a legitimate purpose.

3-) There should be a reasonable link of proportionality between the means used in restrictions and the intended purpose.

Jurisdictional immunity of states which is foreseeing the principle that a state should not be sued before another state court has been accepted by the European Court of Human Rights as "a legitimate purpose" in limiting the right of access to court. In the case of Cudak v. Lithuania Application No: $15869 / 2$ and dated $23.03 .2010^{14}$ it is stated that the application of the principle of state immunity from jurisdiction restricts the exercise of the right of access to a court. "The Court must ascertain whether the circumstances of the case justify such restriction" (parg 59).

The "cautio judicatum solvi" which is a payment of security for legal costs made by a foreigner who does not have a habitual residence in the place of jurisdiction ${ }^{15}$, has been accepted by the European Court of Human Rights as a «serving a legitimate purpose» limitation, but it has been stated that this guarantee can be applied in accordance with the principle of "proportionality». Especially in the case of Tolstoy Milloslavsky v. United Kingdom, dated 13 July 1995 and Application No: 18139/91 ${ }^{16}$, European Court of Human Rights mentioned that "the security for costs order clearly pursued a legitimate aim.... to protect L.A from being faced with an irrecoverable bill for legal costs if the applicant were unsuccessful in the appeal'. Afterwards, since the lack of prospects of success of the applicant's appeal, the impose in the interests of a fair administration of justice should be discussed by taking into account of the principle of proportionality.

In the Zubac v. Croatia decision ${ }^{17}$ of European Court of Human Rights, it is emphasized that determining the monetary value of the case sought for the application to the Supreme Court being too high can be considered within the scope of "restriction at a level that will prejudice the cause of the right". In the same decision, it is stated that having excessively formalist regulations in procedural law provisions may cause a violation of the proportionality principle.

13 Guide on Article 6 of the European Convention on Human Rights - Right to Fair Trial p.26-30. - (Updated: 31 August 2019) and Çayan, p.252.

14 For English version of full text, see, http://hudoc.echr.coe.int/eng?i=001-97879 (31.03.2021)

15 For more information about the term of "cautio judicatum solvi" and its use in Turkish Private International Law, see, Zeynep Çalışkan, Milletlerarası Usul Hukukunda Teminat, Vedat, 2013, p. 33 etc.

16 For English version of full text, see, http://hudoc.echr.coe.int/eng?i=001-57947 (31.03.2021)

17 Overview of European Court of Human Rights Case-Law, 2018 p. 33. 
In the Kurşun v. Turkey decision of European Court of Human Rights dated 30 October 2018 and Application No: $22677 / 10^{18}$, the applicant filed a claim for compensation against Tüpraş due to the damage to his property as a result of the explosion, however, her/his request was rejected by the Supreme Court on the grounds that he did not comply with the one-year prescription period for filing a case against the person who committed the tortious act. However, just a few months before the rejection of the applicant's request, another department of the Supreme Court examined the compensation claims against Tüpraş by other victims of the same explosion. This department constructed the prescription period in favour of the victims, although their claims were not brought forward within one - year after the explosion occurred. While making this comment, it emphasized that the one-year period of prescription should start from the date the injured person learns about the responsible persons. The department which rejected the application did not give a sufficient reason for its decision. The European Court of Human Rights has found the interpretation and application of the prescription period by the relevant department of Supreme Court extremely formal and ruled that the right of access to court had been violated on the ground that this would be contrary to the principle of proportionality.

\section{THE RIGHT OF ACCESS TO COURT AND PRINCIPLES OF FORUM OF NECESSITY}

The right of access to the court creates a multi-dimensional structure due to the international jurisdiction rules of more than one state in private law disputes involving foreign elements. Beside the "positive conflict of jurisdiction" which arises as a result of more than one state court having international jurisdiction in the same dispute, a "negative conflict of jurisdiction" that arises as a result of none of state court has international jurisdiction. Even if there is a legally competent court, the failure to access this court due to extraordinary reasons such as war, natural disaster, epidemic etc. should also be evaluated within this scope ${ }^{19}$. Additionally, in the doctrine, it is stated that there are legal impossibilities in cases where the applied foreign court giving a decision of rejection of international jurisdiction or the parties cannot benefit from a fair trial or rejection of the recognition and enforcement of foreign court decisions and these situations are characterized as absence of an available court ${ }^{20}$.

The principle of forum necessitatis has been developed in order to prevent the violation of right of access to court causes from negative conflict of jurisdiction. The purpose of this principle is to make the court which doesn't have international jurisdiction into a competent one in order to exercise the right of access to the court. However, it is necessary to draw the lines of this principle carefully, which constitutes an exceptional rule. Otherwise, a court decision made in line with the principle of forum

18 For English version of full text see, http://hudoc.echr.coe.int/eng?i=001-187482 (31.03.2021)

19 Özkan, p. 1795 and Aysel Çelikel/ B. Bahadır Erdem, Milletlerarası Özel Hukuk, Beta, 15th ed, 2016, p. 546 and İlyas Arslan, Avrupa İnsan Hakları Sözleşmesinin Milletlerarası Özel Hukuka Etkisi, Adalet, 2019, p.370. 
necessitatis may be considered within the scope of exorbitant jurisdiction and its enforcement in other states can be prevented ${ }^{21}$.

At the source of forum necessitatis principle there is the doctrine of denial of international justice ${ }^{22}$. The purpose of this doctrine, for which there is no consensus in the international doctrine about its content and definition, provides the plaintiff with access to court in the absence of a competent court by the way does not oblige the defendant to defend herself/himself before a court unrelated to the dispute. At this point, it is frequently stated in both doctrine and practice that there should be a certain degree of connection ${ }^{23}$ between the court and the dispute when using the principle of "forum of necessity" to balance the justice between the plaintiff's right of access to court and the defendant's right to defence being damaged by exorbitant jurisdiction rules.

Moreover, in Admissibility Criteria Guide of European Court of Human Rights updated on 31 December $2018^{24}$, it has been stated that these applications will be rejected due to incompatibility in terms of ratione loci if they are related to events occurring outside the territory of the contracting state and there is no link between these events and any authority within the jurisdiction of the contracting state. In order for a state court to consider itself competent despite the lack of reasonable connection with the dispute, the rule governing international jurisdiction must be an exorbitant jurisdiction rule ${ }^{25}$. It is stated in the doctrine that this line should be drawn and the concrete event should be examined in order to determine a reasonable $\operatorname{link}^{26}$. International jurisdiction of a court on the basis of presence or nationality of the defendant or presence in the forum state of the defendant's property is accepted as a reasonable link ${ }^{27}$.

21 Johannes Weber, Universal Jurisdiction and Third States in the Reform of the Brussels I Regulation, The Rabel Journal of Comparative and International Private Law, 75-3, July 2011, p.642.

22 Sarıöz Büyükalp, p. 285-296. Also in Turkish doctrine it is claimed that, as a party of European Convention on Human Rights, Turkey should apply the principle of forum necessitatis. See. Gülin Güngör, Türk Milletlerarası Özel Hukuku, Yetkin, 2021, p. 242.

23 Paul David Mora, Universal Civil Jurisdiction and Forum Necessitatis: The Confusion of Public and Private International Law in Nait - Liman v. Switzerland, p. 179.

$24 \mathrm{https} / /$ www.echr.coe.int/Documents/Admissibility_guide_TUR.pdf (31.03.2021)

25 For more information about the term of "exorbitant jurisdiction" and its boundries, see, Esra Dardağan, Milletlerarası Usul Hukukunda Aşkın Yetki Kavramı, Ankara, 2005, p.73, Nuray Ekşi; Devletler Özel Hukukunda Aşırı Yetki Kuralları, Prof. Dr. S. Sulhi Tekinay’a Armağan, İstanbul, 1999, p. 247-258 and Begüm Süzen, Tanıma Tenfiz Davalarında Kararı Veren Mahkemenin Yetkisinin Denetimi, Oniki Levha, 2016.

26 Burak Huysal, Yabancı Mahkemenin Dava ve Taraflar ile Gerçek Bağlantısının Tanıma ve Tenfiz Üzerindeki Etkisi, Prof. Dr. Ata Sakmar’a Armağan, Galatasaray Üniversitesi Hukuk Fakültesi Dergisi, I, 2011, p. 487.

27 Rolf Stürner, The Principles of Transnational Civil Procedure: An Introduction to Their Basic Conceptions, The Rabel Journal of Comparative and International Private Law, 69 - 2, April 2005, p.217. 


\section{A. Bankoviç and Others v. Belgium and Other NATO Member States}

The European Court of Human Rights Grand Chamber decided inadmissibility on the case of Bankoviç and Others v. Belgium and Other NATO Member States dated 12 October 2001 and Application No: 52207/9928.

The subject of the decision is about one of the air strikes carried out by NATO between 24 March -8 June 1999 during the clashes between Serbian and Kosovo Albanian forces in Kosovo in 1998-1999. Radio Televizije Srbije (RTS), which was in Belgrade was striked by NATO aircrafts at 02.00 am on 23 April 1999. As a result of the missile fired from NATO aircrafts, two floors of the building collapsed and the control room was destroyed. Some of the applicants' children and one's husband lost their lives during the attacks. Afterwards, the applicants who filed a lawsuit at the European Court of Human Rights, claimed that the NATO Member States had a «ratione loci» over the airstrike in the Socialist Federal Republic of Yugoslavia. Thereupon, Grand Chamber examined Article 1 of European Convention on Human Rights, which also refers to the geographical limits of the member states responsibility arising from the convention. In the draft text written by Advisory Council, the article 1 was arranged as «Member States undertake to ensure the rights ... of all persons residing on their territory.» The Expert Intergovernmental Committee aimed to expand the responsibilities of the member states by replacing the phrase "all persons living on its territory" with "those within jurisdiction" in the text. Thus, Article 1 of the European Convention on Human Rights, titled «Obligation to respect Human Rights» has been changed as «The High Contracting Parties shall secure to everyone within their jurisdiction the rights and freedoms defined in Section I of this Convention.»

In its assessment, Grand Chamber stated that the "ratione loci" covers the states territory as a rule. So, "extra territorial jurisdiction" has an exceptional nature. The consulate buildings, sea and air vehicles carrying the flag of the state can be given as examples of this exception.

In terms of the decision examined, it has been determined that the responsible state should have an «effective and comprehensive control» on the place arising dispute in order to apply for extra territorial jurisdiction (parg 71). As an example of effective and comprehensive control, the military occupations, the exercise of all or part of the sovereignty by another state upon the approval, consent or invitation of the administration of the current state are shown. In its examination, Grand Chamber often has made reference to Loizidou v. Turkey decision (dated 18 December 1996 and Application No: $15318 / 89)^{29}$. In that case, European Court of Human Rights determined that Turkey has effective and comprehensive control in the place where the immovable in dispute is located in the island of Cyprus. Therefore Turkey is responsible for the actions and policies in that region. In fact, in the decision, it was stated that the Turkish local administration in the island survive because of Turkey's support.

However, in the case of Bankoviç and Others v. Belgium and Other NATO Member States, Grand Chamber found that the responsible states had limited control over the airspace. For this reason,

28 For English version of full text see, http://hudoc.echr.coe.int/eng?i=001-22099 (31.03.2021).

29 For English version of full text see, http://hudoc.echr.coe.int/eng?i=001-58007 (31.032021). 
stating that the acts of the responsible states which causes the disputes, cannot be associated with their contractual responsibilities, Grand Chamber decided inadmissibility of the case in terms of ratione loci.

\section{B. Markoviç and Others v. Italy and Other NATO Member States}

In the case of Markoviç and Others v. Italy and Other NATO Member States (dated 14 December 2006 and Application No: 1398/03 $)^{30}$, the European Court of Human Rights Grand Chamber decided that the case is admissible and there is no violation of Article 6 of the European Court of Human Rights.

The subject of this decision is the same as the subject in the case of the Bankoviç and Others v. Belgium and Other NATO Member States. However in this issue, unlike the Bankoviç decision, Grand Chamber found a jurisdictional link between the dispute and Italy. Although Italian Court of Appeal denied to have international jurisdiction in this case, applicants based their claims on the organization of the aforementioned air strike within the territory of Italy and the use of Italy's national airspace to carry out the attacks. Grand Chamber found these claims acceptable and decided that the case is admissible, because Italy has a jurisdictional link with the dispute.

\section{Nait - Liman v. Switzerland}

Another decision in which the principle of the forum necessitatis discussed is European Court of Human rights Grand Chamber's decision of Nait - Liman v. Switzerland (dated 15.03.2018 and Application No: $51357 / 07)^{31}$.

In the incident subject to the decision, a Tunisian citizen applicant named Abdennacer NaitLiman was arrested in Italy and extradited to Tunisia in 1992. The applicant, who claimed that he was physically tortured in Tunisia with the order of the Minister of Internal Affairs A.K., fled in 1993 and applied for political asylum in Switzerland. Switzerland accepts the request in 1995. The applicant, who learned that A.K. was being treated in Switzerland in 2001, filed a criminal complaint against A.K., but the investigation was dropped when A.K. left the country. In 2005, the applicant brought a claim for non-pecuniary damage in Switzerland against the Tunisian State and A.K.. The first instance court decided that it does not have international jurisdiction and rejects the case procedurally. Upon the decision in the same direction from the Court of Appeal, the Swiss Federal Supreme Court; rejected the case on the grounds that there is no "reasonable link» ${ }^{32}$ between the subject matter of the case and Switzerland, because the events take place within the sovereignty of the Tunisian State mentioning the principle of jurisdictional immunity of the states. Upon this, Nait-Liman applied to the European Court of Human Rights and claimed that the crime

30 For English version of full text see, http://hudoc.echr.coe.int/eng?i=001-78623 (31.03.2021).

31 For English version of full text see http://hudoc.echr.coe.int/eng?i=001-181789 (31.03.2021).

32 It was stated in the decision that the current residence of the applicant as an asylum seeker is Switzerland does not mean that there is sufficient connection between the event and Switzerland. 
of torture should be outside the scope of the jurisdictional immunity of the states and that the right of access to the court was violated within the scope of Article 6 of the European Convention on Human Rights.

In that decision, the issue discussed before the European Court of Human Rights is whether the domestic courts are obliged under international law to accept the actions for compensation filed by victims of torture committed by a third State abroad or committed within the jurisdiction of a third State ${ }^{33}$. Upon the applicant's claim that Switzerland, which is a party to the Convention against Torture, has universal civil jurisdiction within the scope of Article 14, Grand Chamber stated that the regulation in question «even if it encourages States to do so, cannot be concluded that neither the findings of the Committee against Torture and the discourse of article 14, nor the preparatory work required a State to recognize its universal jurisdiction». It was also stated in the decision that "Aside from the establishment of an international customary that would oblige the Swiss courts to decide that they have jurisdiction to examine the applicant's case, it's not enough yet to show that it has emerged." Nevertheless, Grand Chamber emphasized that the States do not question "be encouraged to recognize impact to this right by granting their court's jurisdiction to examine such claims, including where claims for damages are based on facts that took place outside their boundaries" ${ }^{\prime 34}$.

Grand Chamber emphasized that Swiss Federal Supreme Court did not consider itself having international jurisdiction by using the principle of «forum necessitatis» in Chapter 3 of the Swiss Federal Code on International Private Law, and gave a definition regarding the concept in question. According to this; the principle of forum necessitatis is the principle which «ensures the exceptional jurisdiction adopted by the civil courts of a State in cases where proceedings are impossible or excessively and unreasonably difficult to carry out abroad». While explaining the reason for not applying the principle of forum necessitatis, the Swiss Federal Supreme Court stated that this principle is a part of private international law, not a part of international law, so an international customary rule cannot be established in the application of the forum necessitatis principle ${ }^{35}$.

\section{EXAMPLES OF FORUM NECESSITATIS IN EUROPEAN UNION LAW}

The principle of forum necessitatis is arranged as a general provision in some of the European Union regulations. For example; Regulation (EU) No 4/2009 on jurisdiction, applicable law, recognition and enforcement of decisions and cooperation in matters relating to maintenance obligations on 18 December 2008, in the article $7^{36}$, «Where no court of a Member State has jurisdiction pursuant to Articles 3, 4, 5 and 6, the courts of a Member State may, on an exceptional basis, hear the case if proceedings cannot

33 Overview of European Court of Human Rights Case-Law, 2018 p. 29.

34 For criticism of the decision, see Mora, p.167 etc.

35 Mora, p. 180 etc.

36 For detailed information about the jurisdiction system accepted on this regulation, see, Maire Ni Shúilleabháin, Ten Years of European Family Law: Retrospective Reflections from a Common Law Perspective, The International and Comparative Law Quarterly, 2010, Vol. 59, No. 4 (October 2010), p. 1047. 
reasonably be brought or conducted or would be impossible in a third State with which the dispute is closely connected. The dispute must have a sufficient connection with the Member State of the court seised.»

The principle of forum necessitatis is regulated with the same expressions in Articles 11 regarding the following; - Regulation (EU) No 650/2012 on jurisdiction, applicable law, recognition and enforcement of decisions and acceptance and enforcement of authentic instruments in matters of succession and on the creation of a European Certificate of Succession on 4 July 2012 and Regulation (EU) No 2016/1103 implementing enhanced cooperation in the area of jurisdiction, applicable law and the recognition and enforcement of decisions in matters of matrimonial property regimes on 24 June 2016 and Regulation (EU) No 2016/1104 implementing enhanced cooperation in the area of jurisdiction, applicable law and the recognition and enforcement of decisions in matters of the property consequences of registered partnerships on 24 June 2016.

\section{EXAMPLES OF FORUM NECESSITATIS IN FOREIGN COUNTRY LAWS}

In Article 3 of Switzerland's Federal Code on Private International Law in 18 December 1987 ${ }^{37}$, it is required that " $A$. When this Act does not provide for jurisdiction in Switzerland and proceedings in a foreign country are impossible or cannot reasonably be required, the Swiss judicial or administrative authorities at the place with which the case has a sufficient connection have jurisdiction."

In accordance with Article 11 of Belgian Code of Private International Law on 16 July $2004^{38}$, the forum necessitatis may be applied " when the matter presents close connections with Belgium and proceedings abroad seem impossible or when it would be unreasonable to demand that the action be brought abroad".

In Dutch law, if the foreign court doesn't provide the conditions of fair trial, the forum necessitatis rule can be applied in accordance with article 9 paragraph c of the Dutch Code of Civil Procedure ${ }^{39}$. However, even in such a case, the existence of sufficient connection with Dutch Law must be proven in order to refer to the principle of forum necessitatis.

Since there is a flexible jurisdiction system ${ }^{40}$ in terms of the international jurisdiction of courts in English Law, a general principle of "forum necessitatis" is not envisaged. However, it is available in practice. The first decision to apply the principle of forum necessitatis was Mark and Mark 2004 $(\mathrm{EWCA})^{41}$. In the incident subject to the decision, the Nigerian woman filed a divorce suit against her husband in England, however, the first instance court ruled that it doesn't have international jurisdiction, by reason of the domicilie of the woman. She was staying in England until one year before the case filed but it was unlawful according to the Immigration Law of 1971. The Court of

37 For English translation of this code, see, https://www.unine.ch/files/live/sites/florence.guillaume/files/shared/publications/ pil_act_1987_as_from_1_1_2017.pdf(31.03.2021).

38 For English translation of this code, see, https://sociedip.files.wordpress.com/2013/12/belgica-the-code-of-privateinternational-law-2004.pdf (31.03.2021)

39 For English translation of this code, see, http://www.dutchcivillaw.com/civilprocedureleg.htm (31.03.2021)

40 For more information about the forum shopping principle used in English Courts, see, Shúilleabháin, p.1031-1036

41 See https://www.familylawweek.co.uk/site.aspx?i=ed452 
Appeal ruled that the decision of the first instance court prevented the right of access to court under Article 6 of the European Court of Human Rights and this situation was contrary to public order.

In American Law, although there isn't any rule directly regulating the principle of "forum necessitatis", it is stated that the doctrine of "forum non conveniens", which enables the court to decide that it does not have international jurisdiction if a foreign court has more closely connection with the dispute, indirectly provides the application of the principle of forum necessitatis ${ }^{42}$. Because due to the doctrine of forum non conveniens, the American courts will consider themselves have international jurisdiction in any case where there is no foreign state court having more closely connection with the dispute.

\section{THE FORUM NECESSITATIS IN TURKISH PRIVATE INTERNATIONAL LAW}

\section{A. Legal Regulations}

In Turkish Private International Law, the international jurisdiction of Turkish courts is regulated among articles 41-46 of Act on Private International and Procedural Law numbered 5718 and by the reference of article 40 of this regulation on other national acts about jurisdiction. None of these regulation has a general provision regarding the principle of "forum necessitatis". Also there wasn't any direct provision about this principle on the repealed acts on private international and procedural law dated 1915 and 1982.

There is only a provision in Article 41 of Act on Private International and Procedural Law numbered 5718 that provides the establishment of international jurisdiction of Turkish courts for Turkish citizens who cannot file a lawsuit in a foreign country. In accordance with this provision; «If lawsuits concerning the personal status of Turkish citizens who do not have a domicile in Turkey are not or cannot be filed in the foreign state where they have their domicile and if there is no competent court in Turkey, the lawsuit shall be filed at the place of such citizen's habitual residence; or if the person does not have a habitual residence in Turkey, it shall be filed at his/her last domicile in Turkey. In the absence of a last domicile in Turkey, it shall be filed with the courts of Istanbul, Ankara, or Izmir.»

In the doctrine it is mentioned that, whether the parties don't file lawsuit in a foreign court or the lawsuit could not be filed in a foreign court due to a legal or de facto impossibility, it will be possible for the case to be heard in Turkish courts if it is concerning personal status of a Turkish citizen ${ }^{43}$. Herein, it is aimed to compose a competent Turkish court which is always ready in terms of cases regarding the personal status of Turkish citizens whether they are plaintiff or defendant ${ }^{44}$.

42 Cemal Şanlı/ Emre Esen/ İnci Ataman-Figanmeşe, Milletlerarası Özel Hukuk, 8th ed, Vedat, 2020, p. 368 and Nuray Ekşi, Türk Mahkemelerinin Milletlerarası Yetkisi, 2nd ed., Beta, 2000, p. 62 and Ziya Akıncı, Milletlerarası Özel Hukuk, Vedat, 2020 , p. 115.

43 Mine Tan Dehmen, Türk Vatandaşlarının Kişi Hallerine İlişkin Davalarda Yetki, MHB (33), 1, s.177 Rifat Erten, Türklerin Kişi Hallerine İlişkin Davalarda Türk Mahkemelerinin Milletlerarası Yetkisi, Yetkin, 2017, p. 123-125. Vahit Doğan, Milletlerarası Özel Hukuk, 6th ed, Savaş, 2020, p. 69

44 In Turkish doctrine it is argued that whether this provision creates exorbitant jurisdiction or not. According to an opinion, because this case can be also filed by a foreigner and international jurisdiction of other states are not denied, this provision doesn’t create exorbitant jurisdiction. Bilgin Tiryakioğlu,, Türklerin Kişi Hallerine İlişkin Davalarda Türk Mahkemelerinin Milletlerarası Yetkisi, Tuğrul Arat’a Armağan, Yetkin, 2012, p. 1152 etc. But in the doctrine, it is claimed that the last sentence which provides international jurisdiction to İstanbul, Ankara or İzmir courts, creates exorbitant jurisdiction. Nuray Ekşi, 
In my opinion, it is possible to claim that international jurisdiction of Turkish courts according to the article 41 constitutes from the principle of forum necessitatis. Because, considering the abovementioned international regulations and acts of foreign countries, it is obvious that, two basic criteria must be present for the existence of forum necessitatis principle. The first one is; it should be impossible to file the case in another state court and the second one is; there should be a reasonable link between the state applying the principle of forum necessitatis and the dispute. In the article 41, the failure to file a lawsuit in a foreign state due to a legal or de facto impossibility should be accepted as an indication of the existence of the first criteria. The second criteria, which is a reasonable link between the state that will apply the principle of forum necessitatis and the dispute, is provided by the fact that the plaintiff or defendant is a Turkish citizen.

\section{B. Judicial Decisions}

Although Turkish courts did not have international jurisdiction according to the provisions in force at that time, exceptionally there were some contrary decisions ruled by Turkish Supreme Court. For example, in the decision of Supreme Court of Appeals 2nd Circuit dated 04.06.1945, the divorce case of German spouses, had become impossible to file outside of Turkey, due to the cut of their diplomatic relations with Germany. The Supreme Court established the international jurisdiction of the Turkish courts due to the «de facto impossibility» 45 .

Another decision in which the international jurisdiction of Turkish courts has been established exceptionally is the decision of Supreme Court of Appeals 2nd Circuit dated 02.07.1973. In the incident subject to the decision, a custody dispute related to a foreign child in Turkey was accepted as «public order» and established the international jurisdiction of the Turkish court exceptionally in the case of cancelling the custody between foreign mother and father ${ }^{46}$. In spite of the fact that statements referring to the principle of «forum necessitatis» are not included in these decisions, it is obvious that this principle was applied.

However there are exceptional court decisions mentioned above, in Turkish Law the establishment of a principle of forum necessitatis through judicial decisions, will cause a violation of the provision of 1982 Constitution of Turkish Republic. Because Article 142 paragraph 1 of 1982 Constitution states that the jurisdiction of the courts will only be exist by law. Thus, contrary to common law system, in Turkish Law it is impossible to claim that the international jurisdiction of Turkish court constitutes from judicial decisions.

Yabancı Mahkeme Kararlarının Tanınması ve Tenfizi, Beta, 2013, p. 269-270. Another opinion in this subject, is to decide whether this provision creates exorbitant jurisdiction or not according to the characteristics of each case. Erten, p. 179. 


\section{CONCLUSION}

A general provision on the principle of forum necessitatis is not included among the Turkish international jurisdiction rules. However, two basic criteria must be present in order to mention the existence of forum necessitatis principle. These are; the impossibility to file the case in another state court and the existence of a reasonable link between the state applying the principle of the forum necessitatis and the dispute. The provision regulating the international jurisdiction of Turkish courts in the cases regarding the personal status of Turkish citizens in Article 41 of Act on Private International and Procedural Law numbered 5718 is involving both of these criteria. Therefore, it should be possible to claim that there is a principle of forum necessitatis in the Turkish international jurisdiction system limited by the cases of Turkish citizens regarding their personal status.

Unlike the states having common law system, in Turkish Law the establishment of a principle of forum necessitatis through judicial decisions, will cause a violation of the provision of 1982 Constitution of Turkish Republic. Because Article 142 paragraph 1 of 1982 Constitution states that the jurisdiction of the courts will only be exist by law. However it is obvious that, Turkey, as a party of European Convention on Human Rights, has the responsibility to check whether the plaintiff has the possibility to file a lawsuit in another state court before it makes a decision of rejection of jurisdiction ${ }^{47}$. Thus, it will be able to avoid the European Court of Human Rights decisions regarding a violation of the right of access to court against Turkey. In order to achieve this, it would be appropriate to include a general provision on the principle of forum necessitatis among the Turkish international jurisdiction rules. By this way, exceptional international jurisdiction of Turkish courts will be exist by law according with the Constitution.

\section{REFERENCES}

AKINCI, Ziya, Milletlerarası Özel Hukuk, Vedat, İstanbul, 2020.

ARSLAN, İlyas, Avrupa İnsan Hakları Sözleşmesinin Milletlerarası Özel Hukuka Etkisi, Adalet, Ankara, 2019.

ÇALIŞKAN, Zeynep, Milletlerarası Usul Hukukunda Teminat, Vedat, İstanbul, 2013.

ÇAYAN, Gökhan, Avrupa İnsan Hakları Mahkemesi ve Anayasa Mahkemesi Kararları Işı̆̆ında Mahkemeye

Erişim Hakkı, Türkiye Adalet Akademisi Dergisi, (28), 2016, p. 235 - 271.

ÇELIKKEL, Aysel / ERDEM, B. Bahadır, Milletlerarası Özel Hukuk, 15 ${ }^{\text {th }}$ ed. Beta, İstanbul, 2018.

DARDAĞAN, Esra, Milletlerarası Usul Hukukunda Aşkın Yetki Kavramı, Ankara, 2005.

DOĞAN, Vahit, Milletlerarası Özel Hukuk, $6^{\text {th }}$ ed, Savaş, Ankara, 2020.

DEHMEN TAN, Mine, Türk Vatandaşlarının Kişi Hallerine İlişkin Davalarda Yetki, MHB (33), 1, 2013, p. 169211.

EKŞİ, Nuray: Türk Mahkemelerinin Milletlerarası Yetkisi, $2^{\text {nd }}$ ed. Beta, İstanbul, 2000.

EKŞİ, Nuray, Yabancı Mahkeme Kararlarının Tanınması ve Tenfizi, Beta, İstanbul 2013.

EKŞİ, Nuray, Devletler Özel Hukukunda Aşırı Yetki Kuralları, Prof. Dr. S. Sulhi Tekinay’a Armağan, İstanbul, 1999, p. 247-258.

47 Louwrens Rienk Kiestra, The Impact of the European Convention on Human Rights on Private International Law, Asser Press, Netherlands, 2014, p. 48. 
ERTEN, Rifat, Türklerin Kişi Hallerine İlişkin Davalarda Türk Mahkemelerinin Milletlerarası Yetkisi, Yetkin, Ankara, 2017.

GİRAY, Faruk Kerem, Tenfize İlişkin Üç Soru: Tenfize Konu Yabancı İlâmın Hukuk Devletinden Sadır Olması Gerekir Mi? Arabuluculuk Neticesinde Yapılan Sulh Anlaşması Tenfiz Edilebilir Mi? Yabancı Mahkemeden Sadır Ödeme Emri Kararı Tenfiz Edilebilir Mi?, MHB, (32), 2, 2019, p. 609-643.

GÜNGÖR, Gülin, Türk Milletlerarası Özel Hukuku, Yetkin, Ankara, 2021.

HUYSAL, Burak, Yabancı Mahkemenin Dava ve Taraflar ile Gerçek Bağlantısının Tanıma ve Tenfiz Üzerindeki Etkisi, Prof. Dr. Ata Sakmar’a Armağan, Galatasaray Üniversitesi Hukuk Fakültesi Dergisi, I, 2011, p. 467-502.

KIESTRA, Louwrens Rienk, The Impact of the European Convention on Human Rights on Private International Law, Asser Press, Netherlands, 2014.

MORA, Paul David, Universal Civil Jurisdiction and Forum Necessitatis: "The Confusion of Public and Private International Law in Nait - Liman vs. Switzerland”, Netherlands International Law Review, 65 (2), 2018, p. 155-183.

NOMER, Ergin, Devletler Hususi Hukuku, 22rd ed., Beta, İstanbul, 2020.

ÖZKAN, Işıl, Adil Yargılanma Hakkının Uluslararası Özel Hukuka Etkisi, Dokuz Eylül Üniversitesi Hukuk Fakültesi Dergisi, Prof. Dr. Şeref Ertaşa Armağan, (19), Special Edition, 2017, p. 1777-1834.

PEKCANITEZ, Hakan, Medeni Yargıda Adil Yargılama, İzmir Barosu Dergisi, (2) 1997, p. 35-55.

SARIÖZ BÜYÜKALP, A. İpek, Adil Yargılanma Hakkının Türk Milletlerarası Usul Hukuku Üzerindeki Etkileri, On İki Levha, İstanbul, 2018.

SHUILLEABHAIN Ni, Maire, Ten Years of European Family Law: Retrospective Reflections from a Common Law Perspective, The International and Comparative Law Quarterly, 2010, Vol. 59, No. 4 (October 2010), p. 1021-1053.

STURNER, Rolf, The Principles of Transnational Civil Procedure: An Introduction to Their Basic Conceptions, The Rabel Journal of Comparative and International Private Law, 69 - 2, April 2005, p. 201-254.

SÜZEN, Begüm, Tanıma Tenfiz Davalarında Kararı Veren Mahkemenin Yetkisinin Denetimi, Oniki Levha, 2016.

ŞANLI, Cemal / ESEN, Emre / ATAMAN-FIGANMEŞE, İnci, Milletlerarası Özel Hukuk, 8th ed, Beta, İstanbul, 2020.

TİRYAKİOĞLU, Bilgin, Türklerin Kişi Hallerine İlişkin Davalarda Türk Mahkemelerinin Milletlerarası Yetkisi, Tuğrul Arat’a Armağan, Yetkin, Ankara, 2012, p. 1141-1165.

WEBER, Johannes, Universal Jurisdiction and Third States in the Reform of the Brussels I Regulation, The Rabel Journal of Comparative and International Private Law,75-3, July 2011, p. 619-644.

\section{EUROPEAN COURT OF JUSTICE DECISIONS:}

Ashingdane v. United Kingdom (Application No: 8225/78, 28/5/1985)

Bankoviç and Others v. Belgium and Other NATO Member States (Application No: 5220/99, 12/10/2001)

Bellet v. France (Application No: 23805/94, 04/12/1995)

Cudak v. Lithuania, (Application No: 15869/2, 23/03/2010)

Geffre v. France, (Application No: 51307/99, 23/1/2003)

Golder v. United Kingdom (Application No: 4451/70, 21/02/1975)

Kurşun v. Turkey (Application No: 22677/10, 30/10/2018) 
Loizidou v. Turkey (Application No: 15318/89, 18/12/1996)

Markoviç and Others v. Italy and Other NATO Member States (Application No: 1398/03, 14/12/2006)

Nait - Liman v. Switzerland (Application No: 51357/07, 15/03/2018)

Tolstoy Milloslavsky v. United Kingdom, (Application No: 18139/91, 13/07/1995)

Zubac v. Croatia (Application No: 40160/12, 05/04/2018) 